\title{
REVIEW | Fela: Kalakuta Notes
}

John Collins

Middleton, MN: Wesleyan University Press, 2015. Second edition.

ISBN: 9780819575395 (PB)

\section{Michael Drewett}

Rhodes University

michaelatcuttinggrooves@gmail.com

Over the past two decades there has been a growing bibliography on the life and music of Fela Kuti (see for example Moore 2009; Olaniyan 2004; Olorunyomi 2002; Veal 2000), and the second edition of John Collins' book on Fela Kuti is an important addition to the Fela Kuti and Afrobeat canon. In this edition of his insightful and mostly first-hand account on Fela Kuti's life and legacy, John Collins has added a new 50 page concluding chapter that very usefully documents Fela's legacy - from the musical lives of Fela's family members to the continuing spread of Afrobeat and the development of Fela's Africa Shrine and the growth of the annual Felabration festival. As Collins explains (209), "[t]his is a good opportunity to update the book and look as the way Afrobeat continues to flourish in Africa and spread internationally". This additional chapter leaves no doubt as to the importance of Fela Kuti, not only during his lifetime but subsequently too. In this regard, for both ethnomusicologists and popular music scholars the second edition becomes an even more valuable resource than the first edition.

Indeed, the book as a whole offers penetrating personal insights into Kuti's personality and music. The fact that the book is based on Collins' own diary notes is what, in many ways, makes it a unique document on Kuti's life and works. Given that diaries are often used by their authors as confessionals, telling things as one sees them, with often unedited thoughts and observations, they offer the possibility of new insights. In this way, such notes provide a portrait of Kuti that is complicated and complex, showing him to be a creative genius, as well as 
controlling and misogynist. I finished reading the book feeling both admiration for Fela Kuti and disappointment at some of his personal conduct. I had previously read about Kuti's sexism but Collins' frank, detailed and honest accounts of Kuti's behaviour, through his own experience and according to eye witnesses he spoke to at the time, provide graphic detail that adds detailed evidence to those accounts. This book makes it clear that while being a prolific musician and determined political activist, Fela Kuti was also an undemocratic and maverick band leader who bordered on being a cult leader, with whom it was not always pleasant to work with, especially as a woman.

Thus, Collins' account repeats the well-known narrative of the young Fela Kuti trying to push musical barriers and developing his own style of Afrobeat music, while at the same time becoming an outspoken critic of a succession of corrupt Nigerian governments. It also documents the repressive retaliation by these governments and their police force. It does so by providing detailed accounts of those events that occurred at the time Collins was working with Kuti in January 1977 on the autobiographical film The Black President. He was employed as an actor, playing the role of a colonial inspector at Fela's school. In this sense, the book takes on the impression of good qualitative research, providing rich insights into certain events, rather than broadly sweeping across Kuti's career. The famous raid on Fela's "Kalakuta Republic" compound by Nigerian soldiers is well documented, and details about the loss of irrecoverable sound material for The Black President are particularly disheartening.

Although Collins offers a particular focus on his diary notes from 1977 when he worked with Kuti in Nigeria and Ghana, the book does provide an overview of Kuti's career, within which he situates his own encounters with Kuti. Most of all, Collins provides an important account of Afrobeat, from its early development through to contemporary manifestations. Some might find the new chapter a little dry, as at times it merely lists new developments rather than builds them into a flowing narrative but they do provide an excellent resource, not only for the interested scholar, but also to anyone with an interest in Fela Kuti, Afrobeat or West African music in a more general sense.

\section{References}

Moore, C. 2009. Fela: The Bitch of a Life. Chicago, IL: Chicago Review Press.

Olaniyan, T. 2004. Arrest the Music! Fela and His Rebel Art and Politics. Indianapolis: Indiana University Press.

Olorunyomi, S. 2002. Afrobeat: Fela and Imagined Continent. Trenton: Africa World Press.

Veal, M. 2000. Fela: The Life and Times of an African Musical Icon. Philadelphia: Temple University Press. 